Jurnal ASPIKOM, Vol. 6, No. 2, July 2021, pp. 360-372

P-ISSN: 2087-0442, E-ISSN: 2548-8309

DOI: http://dx.doi.org/10.24329/aspikom.v6i2.934

\title{
Identifying Personal Characteristics of Social Media Entrepreneurs in Indonesia
}

\section{Mengidentifikasi Karakteristik Pribadi Wirausaha Media Sosial di Indonesia}

\author{
Eliot Simangunsong \\ Universitas Prasetiya Mulya, Jl. R.A. Kartini Cilandak Jakarta Selatan, Indonesia \\ Corresponding author, e-mail: elliot@pmbs.ac.id
}

\begin{abstract}
Social media is currently not only used to communicate with friends but as a platform for business. This trend has been increasing since the Covid-19 pandemic, where more and more people are using it to buy and sell. However, there are doubts in running a business through social media, i.e., the absence of the right business strategy, understanding of business competition, and the personal characteristics of the people it needs. Therefore, this study aims to determine the ideal personal characteristics needed in running a social media-based business. Using qualitative research methods, data analysis from 20 interviews identifies twelve characters, six of which are critical to someone who has good potential to do business on social media and who can make the most of it. The suitability of an entrepreneur's character and the demands of doing business on social media will lead to positive attitudes that are key to business success.
\end{abstract}

Keywords: Business operations; Digital era; Personal characteristics; Social commerce; Social media

\begin{abstract}
Abstrak
Media sosial saat ini tidak hanya digunakan untuk berkomunikasi dengan teman-teman tetapi sebagai platform untuk bisnis. Tren ini semakin meningkat sejak pandemi Covid-19 di mana semakin banyak orang yang menggunakannya untuk transaksi jual beli. Namun banyak keraguan dalam menjalankan bisnis melalui media sosial, misalnya tidak adanya strategi bisnis yang tepat, pemahaman tentang persaingan bisnis dan karakter pribadi personel yang dibutuhkan. Oleh karena itu, penelitian ini bertujuan untuk mengetahui karakteristik pribadi ideal yang dibutuhkan dalam menjalankan bisnis berbasis media sosial. Menggunakan metode penelitian kualitatif, analisis data dari 20 wawancara, penelitian ini mengidentifikasi dua belas karakter, enam di antaranya sangat penting bagi seseorang yang memiliki potensi baik untuk berbisnis di media sosial dan yang dapat memanfaatkannya sebaik mungkin. Kecocokan karakter seorang wirausaha dengan tuntutan berbisnis di media sosial akan mengarah pada sikap positif yang menjadi kunci kesuksesan bisnis.
\end{abstract}

Kata Kunci: Era digital; karakteristik pribadi; Media sosial; Pperasi bisnis; Social commerce 


\section{Introduction}

Today, the internet has become an essential tool in our daily life, and we cannot imagine a day without it. Asia has become the region with the most online users, with more than 2 billion in 2018, while Europe ranks second with 705 million internet users (Statista, 2020). In terms of social networks, Facebook is the first social network to surpass 1 billion users and currently has more than 2.6 billion monthly active users. Instagram, which is popular in Indonesia, has more than 1 billion monthly active accounts (see Table 1 below). Overall, the number is associated with about $45 \%$ of the current world population (Tjepkema, 2019). In Indonesia, research conducted by Riyanto (2020) stated that YouTube, WhatsApp, Facebook, Instagram, and Twitter are the most frequented social media apps. Of Indonesia's 272 million population, about 175 million have internet connections, and among those with internet connections, about 160 million are active social media users.

Table 1. Ten Most Popular Social Networks Worldwide as of July 2020

\begin{tabular}{ccc}
\hline No & Social Media Apps & Number of Active Users in Millions \\
\hline 1 & Facebook & 2,603 \\
2 & Youtube & 2,000 \\
3 & WhatsApp & 2,000 \\
4 & Facebook Messenger & 2,000 \\
5 & Weixin/WeChat & 1,300 \\
6 & Instagram & 1,082 \\
7 & TikTok & 800 \\
8 & QQ & 694 \\
9 & Sina Weibo & 550 \\
10 & QZone & 517 \\
\hline
\end{tabular}

A recent analysis by eMarketer (2018) shows the social media usage by generation, and the results and the results were fascinating. Social media users comprise $90.4 \%$ of Millenials, $77.5 \%$ of Generation X, $48.2 \%$ of Baby Boomers. Millennials take up the spot as the generation with the highest use of social media, which can be credited to the accessibility to smartphones.

In its early days, social media was used to connect one individual with another, share information, entertain themselves, and engage with various news content. However, it has evolved into a platform for business. Social media is a media that connects with the computer network, internet, and others that bring simplicity to its users, from interacting with each other, selling and buying goods, and sharing information. Social media is a network-based technology that also functions as an interactive platform for individuals and groups so that they can communicate and share information (Kietzmann et al., 2011; Kahar et al., 2012; Arisanty et al., 2020). Social media can be classified into blogs, social networking sites, virtual social worlds, projects with collaborations, communities, along with gaming and virtual worlds (Gavino et al., 2018). Today, with devices connecting to the internet, online transactions 
are possible. There are numerous social media to advertise products, from Facebook, Instagram, Tiktok, among others. Additionally, the product offered various items from foods, clothes, and houses to luxurious items such as posh cars, jewelry, and high-end couture. It has been proven as a cost-effective tool to help companies and business owners to reach a wider consumer (Ahmad et al., 2019). Additionally, the development of social media has enabled users to cope with massive information sharing from anyone, anytime to everyone (Cahyono, 2016).

A survey conducted by the Katadata Insight Center (2020) of 206 respondents, namely small and medium enterprises, stated that most of them use a number of devices such as laptops or PCs to build their businesses. In addition, it is interesting to note that $60.2 \%$ of respondents stated that they advertise their products through social media. It also shows that $55 \%$ of respondents use social media for their exclusive use, to interact and communicate with each other. Therefore, it can be said that in Indonesia, social media has an important role in the business world.

In another development, during the first quarter of 2020, countries around the globe have faced one of the worst pandemics (Limilia \& Pratamawaty, 2020). There are various industries that are most affected by COVID-19, such as the service industry (hospitality/tourism) and the food and beverage sector, which sell their services onsite (Bayu, 2020; ILO, 2020). According to the Chairman of the Indonesian Shopping Centre Alliance (Hippindo), Budihardjo Iduansjah, the retail industry has over 50\% decline in revenue (Kontan, 2020). For business survival, stakeholders are challenged to cope with digital adoption due to the changes in customer behavior (Accenture, 2020).

Here, the COVID-19 pandemic has increased the trend of doing business through social media. With lockdowns initiated at various locations, there is an increase in the adoption of digital channels and the use of the internet around the globe (Eoin Daly et al., 2020; Limilia \& Pratamawaty, 2020). A recent study by Google \& Temasek (2020) also reported that the coronavirus had caused massive adoption of digital services among customers in Indonesia, estimated with over $37 \%$ new digital services consumers, where $90 \%$ of them will continue their digital habits post-pandemic. However, the recognition of this social media business is still very much needed from the Indonesian government because of its resilience to face this challenging pandemic period (Arisanty et al., 2020).

Business leaders and entrepreneurs have to take innovative steps to provide customers' needs post-pandemic (Accenture, 2020). Although social media has been known to bring simplicity to its users, especially for business owners, some do not know how to use it effectively. Many business owners believe that social media is only a platform to introduce their products, and their goal is to open an offline retail store. This is clearly not enough because they have to create a social media plan as part of a business strategy to keep up with the pace of changing consumer trends. Ignoring this can backfire, resulting in the company failing to achieve the desired performance (Jussila et al., 2014). This point of view is aligned with Ejupi's study (2017) that identifies social media as a very different business platform that differs from the conventional business. An examination conducted by Jussila et al. (2014) explains that there is still a lack of expertise for such business activities involving social media. Social media knowledge is still scarce among business owners. There are many questions about online businesses that rely on social media, so more studies and reports are needed to help business owners who rely heavily on social media to maximize their growth. A recent study conducted by Simangunsong \& Handoko (2020) has uncovered 
the role of social media in Indonesia for business activities and identified major factors that can influence/convert followers into actual buyers. They found that personal characteristics are a significant contributor to positive business performance done through social media, but not enough explanation is given in this study. Another study by Ahmad et al. (2019) also identified the organization as one of the factors that can influence social media adoption. However, this study found that there is still a lack of understanding of the personal character of business people on social media. Further research is needed to explore these personal character factors in more detail and depth.

Therefore, this study aims to identify ideal personal characters in running a business that relies on social media. Due to many doubts about online business through social media, it is expected that the results of this study can help and encourage business owners who rely heavily on social media to be able to make optimal use of it. Businesses that rely on social media have proven to be able to withstand economic challenges during the COVID-19 pandemic, so the dissemination of this research is important and urgent because of its contribution to economic recovery in Indonesia.

\section{Method}

This research aims to identify an ideal personal character in running a business that relies on social media. Previous studies (Cahyono, 2016; Ejupi, 2017; He et al., 2017; Arisanty et al., 2020) have used qualitative research to explore the social media phenomenon. This method was chosen because it allows a large amount of relevant and applicable data to be available. These studies have also suggested that rich data can be applied to identify personal characteristics. Therefore, qualitative research using deep interviews has been selected in this study to obtain the required data. Additionally, a large volume of data collection also acquiesces with Yin's concept of dynamic research (Yin, 2013). Previous studies were used to establish criteria to clarify potential candidates and define units of analysis. The gaps found in previous studies were also used to improve interview procedures.

Qualitative studies generally use a small sample size with the intention of a deeper analysis. Hence, judgmental sampling is favored over random sampling (Miles \& Huberman, 1984). Respondents were carefully selected to meet the required criteria, i.e., respondents who run businesses on social media or socialmediapreneurs. For data collection, interviews were conducted with 20 respondents. All backgrounds and profiles of respondents have met the requirements of individuals doing business on social media, as explained in the previous section. The interviews were conducted in Indonesia's four major cities, i.e., Greater Jakarta Area, Surabaya, Yogyakarta, and Medan. This helps to enhance the data obtained for analysis. Sorting out respondents from various areas across Indonesia also improves the validity and reliability of the findings.

Due to the recent COVID-19 pandemic, the process of in-depth interviews was organized online. In-depth interviews through Zoom and Google Meet were conducted with socialmediapreneur to gain deeper insight into their personal character and their methods and strategies for running their business through social media based on the previous theories. Respondents can be assumed to be valid because they have implemented the way of selling through social media so that the interview data obtained is relevant to the research objectives. The consistency and stability of the data collection process, namely reliability, is achieved by applying the same criteria in selecting potential respondents and the question cycle for each interview. 
Stemler (2001) stated that implementing word-frequency count is a well-known method in content analysis. The data processing begins by doing inputs to the transcripts from the 20 interviews, followed by implementing coding on the keywords that were related to the research, then by making data reduction from the available codes. Next, we chose a few keywords that relate to the topic of our research for coding. We also performed data reduction to avoid words like " $d i$ ", "ke" and the likes that were not important to our study. The words frequently mentioned are considered the words that reflect the most significant concern. This can be used to code and classify the data. Here, the frequency of selected words is analyzed to identify the main keywords that will then be visualized (data display) in a knowledge network. Finally, classified codes were compared to see their correlation with each other and identify possible triangulation of findings and results from data analysis.

To help carry out this content analysis, Atlas.ti software version 9 (https://atlasti.com) was used. Analysis of the qualitative data is expected to offer sufficient knowledge for readers and local business owners through in-depth observation of the influence of personal character on product sales, strategies for choosing the right social media to run a business, and the effects of social media on the industry. Personal biases were avoided to meet the requirements. Each interview was recorded and voice transcribed. The results of this analysis are presented by integrating previous research findings to enhance credibility further. In this study, standard criteria were used for the selection of interviewees in the Indonesian context. Therefore, it is possible for other researchers to replicate this research and consider the results to be applicable.

\section{Results and Discussion}

This study defines socialmediapreneur as an individual who takes the opportunity to introduce and market their product through various social media platforms. They are also known as the individuals who use social media to expand their network, search for information, and crowdfunding for their business. The emerging social media industry is created with the presence of entrepreneurs who take the risk of introducing and presenting products on social media in response to available opportunities. Today, with only a laptop or any gadget connected to the internet, online selling is possible. There are various social media options to market products, such as Facebook, Instagram, TikTok, Youtube, and others.

As the unit of analysis in this study, interviews were conducted with socialmediapreneurs at the end of 2019. After being slightly delayed due to the COVID19 pandemic, interviews were continued in mid-2020 online via Google Meet and Zoom. A research assistant assists the interviewer by taking notes and recording audio of the entire interview. The duration of each of these interviews was between 60 and 90 minutes. A report consisting of notes and recorded voice transcriptions were created after each interview. Overall, extensive interviews were conducted with 20 respondents consisting of 7 men and 13 women. Each one of them is socialmediapreneurs because they were actively using social media for their business. Most of the interviewees' educational background is a bachelor's degree or higher $(55 \%)$, followed by university students (35\%) and senior high school students (15\%). The average age is 28 years old, extending from 16 years old to 47 years old. 
Table 2. Educational background

\begin{tabular}{lcc}
\hline \multicolumn{1}{c}{ Education } & Number of Interviewees & Percentage \\
\hline Senior High School & 3 & $15 \%$ \\
University Students & 6 & $30 \%$ \\
Bachelor degree & 11 & $55 \%$ \\
Master degree & 1 & $5 \%$ \\
\hline Total & 20 & $100 \%$ \\
\hline
\end{tabular}

The respondents mostly reside in Jabodetabek (5 interviewees), Surabaya (5 interviewees), Medan (4 interviewees), and Yogyakarta (6 interviewees). The diversity of these sources adds to the richness and extensive understanding of the problem being investigated.

Table 3. The location of the interviewee's domicile

\begin{tabular}{ccc}
\hline City & Number of Interviewees & Percentage \\
\hline Jabodetabek & 5 & $25 \%$ \\
Surabaya & 5 & $25 \%$ \\
Medan & 4 & $20 \%$ \\
Yogyakarta & 6 & $30 \%$ \\
\hline Total & 20 & $100 \%$ \\
\hline
\end{tabular}

In the context of the study, interviewees were asked what social media they use for their daily activities. The results showed there is a diversity in interviewees in terms of what social media they use. Instagram stands out as the most used social media (32\%), followed by Facebook and WhatsApp (20\%). Line ranks fourth (17\%) of the six popular social media used, followed by Twitter (8\%) and OLX (3\%) as the least used social media.

Table 4. Social Media used by the interviewees

\begin{tabular}{ccc}
\hline Social Media & Number of Interviewees* & Percentage \\
\hline Facebook & 12 & $20 \%$ \\
Instagram & 19 & $32 \%$ \\
Line & 10 & $17 \%$ \\
OLX & 2 & $3 \%$ \\
Twitter & 5 & $8 \%$
\end{tabular}




\begin{tabular}{ccc} 
WhatsApp & 12 & $20 \%$ \\
\hline Total & 20 & $100 \%$ \\
\hline
\end{tabular}

Most interviewees are actively utilizing Instagram as their main platform to do business activities (73\%). While Line, OLX, and WhatsApp became the second most used social media (8\%), Facebook was the least used social media for business (4\%). The gap between the first and second most used social media showed that business activities are centralized in Instagram. This finding is different from previous research, showing Facebook as the most popular social media (Legowo \& Noer, 2017; Statista, 2020). On the other hand, the findings are in line with Paxel's (2021) results, which found that Whatsapp and Instagram are the two main channels chosen to sell online in Indonesia. The study by Paxel (2021) focuses on small and medium-sized businesses, similar to this study. Therefore, it is reasonable to assume that socialmediapreneurs prefer Instagram over Facebook or other social media in doing business on social media for small and medium-sized businesses. It is also common for socialmediapreneurs to use more than one platform to run their business.

Table 5. Social Media used for Business

\begin{tabular}{ccc}
\hline Social Media & Number of Interviewees* & Percentage \\
\hline Facebook & 1 & $4 \%$ \\
Instagram & 19 & $73 \%$ \\
Line & 2 & $8 \%$ \\
OLX & 2 & $8 \%$ \\
WhatsApp & 2 & $8 \%$ \\
\hline Total & 20 & $100 \%$
\end{tabular}

After descriptive analysis, the next step is qualitative data analysis by applying content analysis to the transcript data of 20 interviews. The Atlas.ti software is widely used as a tool for data analysis. The first step is to reduce data by identifying keywords from qualitative data. The identified keywords are then counted for their frequency, both in terms of the number of words and the number of respondents who said these words.

The main keywords found were then triangulated to find relationships between keywords and test the findings' validity. In general, it is assumed that a keyword is considered valid if it is mentioned frequently and has a strong relationship with more than one source. These keyword findings are then used for final coding and classifying the research findings.

The results of data analysis show a total of twelve main keywords that represent the personal character of the interviewees. Further analysis shows that the keywords can be paired into six pairs where each pair is two contrasting characters. The list of keyword pairs is as follows:

1. Emotionally stable vs. prone to emotional outbursts

2. Lack of interest in new things and networking vs. interest in new things and 
networking

3. Apathetic vs. Energetic

4. Like to make friends vs. does not like to befriend others

5. Not easily anxious vs. easily anxious

6. Talkative vs. non-talkative person

Each pair of findings above will be explained as follows. For the first pair, the previous study, such as Bitner (1992), explained that emotions affect one's decisionmaking as both a consumer and a producer. For example, an emotionally repressed person may directly hinder the achievement of his goals or may limit his ability to do his job. On the other hand, creating a conducive emotional atmosphere in the business environment positively impacts customer purchase intentions (Mazaheri et al., 2012). The finding of this study supports previous studies because the analysis results generally show that for entrepreneurship in social media, emotionally stable characters are expected more than characters who are prone to emotional outbursts. Here, for example, giving in and listening to others are major factors of an emotionally stable person. Dealing with other people's disrespectful attitudes is the cause for the emotional outburst of the interviewee. Emotionally stable entrepreneurs have a strong relationship with satisfaction levels using social media (Correa et al., 2010).

Next, in how the interviewee perceives new things, the dominant character shown is interest in new things and networking compared to the character who dislikes new things. Interest in new things and networking can be seen, for example, in interviewees looking for adrenaline excitement, social butterflies, and a love of exploring things that suit their passions. Having a personal character who likes to find new things in doing business using social media is also supported by previous studies by Nunez-Zabaleta (2019). They found that people who actively use social media to build professional networks help get work done faster through collaboration and knowledge sharing. Another study by Rahbi \& Abdullah (2017) identifies that people interested in new things like new technology are easy to find in the wholesale and retail industry because of the nature of the business.

The study by Rahbi \& Abdullah (2017) also found that passionate people are an important factor in the success of using social media for business. The energetic character of interviewees in this study was found to be two times more often than interviewees who were not energetic. This signifies the energetic character of a person as an essential trait of a socialmediapreneur. Energetic traits, the third keyword pair, are closely related to a brave personality, adrenaline pleasure, and motivation to be friends with most people (social butterflies). On the other hand, interviewees who are nonenergetic in character are due to their overthinking behavior and tend to act according to the nature of the situation.

Interviewees who like to make friends are more dominant than those who are picky in making friends. They are generally characterized by the desire to be friends with everyone (social butterfly), are happy when invitations from friends, and quickly adapt to circumstances. Many studies, such as the one discussed in Olanrewaju et al. (2020), agree that having many friends who are active on social media has a big impact on the success of social media activities, such as crowdfunding. Individuals who have many friends on social media generally have social power that can influence their friends' attitudes, opinions, decisions, and actions (Arisanty et al., 2020). On the other hand, people who are picky in making friends tend to have unique characteristics, independent people, and passive personalities. 
For the fifth keyword pair, this study found that a character who does not get anxious is equivalent to a character who gets anxious easily. From these findings, it is quite evident that anxiety is not a differentiating factor for people who are actively doing business on social media. The result of this study is different from another study by Correa et al. (2010), who argue that anxious people tend to use social media more often than those who do not, especially for the male gender. However, the study only found indications of the frequency of web use. More research is still needed to find out if someone experiencing social anxiety also affects the performance of doing business on social media.

Ismail (2017) suggests that a talkative character is an important trait for entrepreneurs. Our finding for the sixth keyword pair confirms that from all the interviewees, the talkative character proves to be much superior to the non-talkative character. The desire to be friends with everyone (social butterfly) is the main driving force for a person to have a personal character who likes to talk, in addition to a liking to being happy and the desire always to ask questions. At the same time, quiet people are more often characterized as independent people, like written correspondence and who are moody.

The number of interviewees who had good social media technology skills was much larger than the interviewees who felt their skills were mediocre or who only knew moderately. From these findings, it can be assumed that social media utilization skills are an important requirement if one wants to do business using social media.

The main findings above can be summarized below, which are used to identify the main personal characteristics of a person doing business on social media. In many cases, a person's emotional state's key to business success and satisfaction is expressed when experiencing happiness or a positive attitude towards his work and efforts (Konstantopoulou et al., 2016). With more and more local businesses popping up accompanied by expensive store rental prices, social media has become the right choice for business people to sell their products. There is sufficient evidence to conclude that the following characteristics are the key to a person running their business on social media:

- Emotionally stable. Being willing to give in and listening to other people is a key indicator of an emotionally stable person.

- Interest in new things and networking. Shown by someone who is looking for an adrenaline rush, social butterflies, and a love of exploring things that suit their passions

- Energic. Energetic traits can be seen from the indication of a brave personality, adrenaline pleasure, and motivation to be friends with most people (social butterflies).

- Like to make friends. Generally indicated by the desire to be friends with everyone (social butterflies), happy when there are invitations from friends, and easy to adapt to circumstances.

- Talkative character. It can be indicated from the desire to be friends with everyone (social butterfly), the desire to be happy and the desire to always ask questions. Social media technology utilization skills. 
The six personal characters above are the characteristics expected of someone who has great potential to succeed in doing business using social media. The results of this study are consistent with previous research. For example, a study by $\mathrm{He}$ et al. (2017) agrees that personal characteristics are an important factor in making decisions about adopting the use of social media for business. Another study also supports the finding that people who like to make new friends (social butterfly) will use social media more often (Gosling et al., 2011) and have the potential to be more successful in doing business in it. Finally, a study by Correa et al. (2010) also supports that individuals who like new experiences (an energetic person) have the potential to do good business because they tend to use social media more often than less energetic people.

It should be noted that the results of this study have some limitations that should be considered. First, interviewees represent four major cities (national and provincial capitals) in Indonesia. Further research from informants in district capitals or other small cities is still needed to ensure similar findings. Second, due to the nature of the qualitative research used here, further research may be needed to examine the six personality traits identified in this study through quantitative research (surveys) to test the generalizability of the findings of this study. Finally, it is also possible for additional research to identify more specific subcategories of the personality traits identified in this study. This can provide a more comprehensive picture of the characteristics needed to do business successfully on social media.

\section{Conclusion}

This study provides enough evidence that social media has been used for business. Instagram has been selected by most interviewees as their main platform to do business activities, followed by Line, OLX, and WhatsApp. It is interesting to note that Facebook has the least used social media for business.

Qualitative data analysis by applying content analysis to 20 interviews data enables identification of 12 main keywords, i.e., personal characteristics of socialmediapreneur. Keywords are identified after the frequency is calculated, both in terms of the number of words and the number of respondents who said these words and after triangulation to find relationships between keywords and test the findings' validity. The 12 personal characteristics are: being emotionally stable, prone to emotional outbursts, lack of interest in new things and networking, interested in new things and networking, apathetic, energetic, like to make friends, does not like to befriend others, not easily anxious vs easily anxious, talkative and finally non-talkative person.

Further analysis using the Atlas.ti software allows the identification of key findings that characterize individuals who have great potential to run a business using social media. There is sufficient evidence to conclude that the following characteristics are the key to a person running their business on social media: emotionally stable, interested in new things and networking, energetic, like to make friends, and talkative character. In addition, this study also identified that social media technology utilization skills are also important for the success of business ventures using social media.

The results of this study are expected to help create new entrepreneurs on social media and for social media entrepreneurs today who rely heavily on social media in order to make optimal use of it. This can help accelerate business and economic growth in Indonesia, which is getting worse due to the COVID-19 pandemic. 


\section{Acknowledgements}

This research was supported by The Ministry of Research, Technology and Higher Education Republic of Indonesia and Universitas Prasetiya Mulya.

\section{References}

Accenture. (2020, May 22). A new era in customer engagement | Accenture. https://www.accenture.com/mu-en/insights/consulting/coronavirus-new-eracustomer-engagement

Ahmad, S. Z., Bakar, A. R. A., \& Ahmad, N. (2019). Social media adoption and its impact on firm performance: The case of the UAE. International Journal of Entrepreneurial Behavior \& Research.

Arisanty, M., Wiradharma, G., \& Fiani, I. (2020). Optimizing Social Media Platforms as Information Disemination Media. Jurnal ASPIKOM, 5(2), 266. https://doi.org/10.24329/aspikom.v5i2.700

Bayu, D. J. (2020). 6 Sektor Usaha Paling Terdampak saat Pandemi Corona | Databoks. https://databoks.katadata.co.id/datapublish/2020/09/15/6-sektor-usahapaling-terdampak-saat-pandemi-corona

Bitner, M. J. (1992). Servicescapes: The impact of physical surroundings on customers and employees. Journal of Marketing, 56(2), 57-71.

Cahyono, A. S. (2016). Pengaruh media sosial terhadap perubahan sosial masyarakat di Indonesia. Jurnal Publiciana, 9(1), 140-157.

Correa, T., Hinsley, A. W., \& De Zuniga, H. G. (2010). Who interacts on the Web?: The intersection of users' personality and social media use. Computers in Human Behavior, 26(2), 247-253.

Ejupi, R. (2017). The use of Social Media as a marketing tool in Kosovo: Current trends and opportunities.

eMarketer. (2018). US Social Media Users, by Generation, 2019 (\% of population). Insider Intelligence. https://www.emarketer.com/chart/226029/us-social-mediausers-by-generation-2019-of-population

Eoin Daly, Kaushik Das, \& Rebecca Yeoh. (2020). Reimagining emerging ASEAN in the wake of COVID-19. https://www.mckinsey.com/featured-insights/asiapacific/reimagining-emerging-asean-in-the-wake-of-covid-19\#

Gavino, M. C., Williams, D. E., Jacobson, D., \& Smith, I. (2018). Latino entrepreneurs and social media adoption: Personal and business social network platforms. Management Research Review, 42(4), 469-494. https://doi.org/10.1108/MRR-022018-0095

Google, \& Temasek. (2020). E-Conomy SEA 2020 (5th edition; p. 128). Google, Temasek, Bain and other third parties. https://economysea.withgoogle.com/

Gosling, S. D., Augustine, A. A., Vazire, S., Holtzman, N., \& Gaddis, S. (2011). Manifestations of personality in online social networks: Self-reported Facebookrelated behaviors and observable profile information. Cyberpsychology, Behavior, and Social Networking, 14(9), 483-488.

He, W., Wang, F.-K., Chen, Y., \& Zha, S. (2017). An exploratory investigation of social media adoption by small businesses. Information Technology and Management, $18(2), 149-160$.

ILO. (2020, September 14). Business and COVID-19 [Document]. https://www.ilo.org/global/topics/coronavirus/keyresources/WCMS_741005/lang--en/index.htm 
Ismail, A. B. (2017). We are different: A case study of entrepreneurship education in Malaysia [Phd, Queensland University of Technology]. https://eprints.qut.edu.au/102894/

Jussila, J. J., Kärkkäinen, H., \& Aramo-Immonen, H. (2014). Social media utilization in business-to-business relationships of technology industry firms. Computers in Human Behavior, 30, 606-613. https://doi.org/10.1016/j.chb.2013.07.047

Kahar, R., Yamimi, F., Bunari, G., \& Habil, H. (2012). Trusting the Social Media in Small Business. Procedia - Social and Behavioral Sciences, 66, 564-570. https://doi.org/10.1016/j.sbspro.2012.11.301

Katadata Insight Center. (2020, June). Internet Mendukung UMKM Jangkau Pelanggan. https://databoks.katadata.co.id/datapublish/2020/06/27/internet-mendukungumkm-jangkau-pelanggan

Kietzmann, J. H., Hermkens, K., McCarthy, I. P., \& Silvestre, B. S. (2011). Social media? Get serious! Understanding the functional building blocks of social media. Business Horizons, 54(3), 241-251. https://doi.org/10.1016/j.bushor.2011.01.005

Konstantopoulou, E., Naoum, V., Skiathitis, G., \& Apostolakis, I. (2016). Investigation of business satisfaction of medical and nursing staff of the Naval Hospital of Athens. International Journal of Caring Sciences, 9(3).

Kontan. (2020, October 9). Hippindo: Hingga akhir tahun, penjualan ritel terancam $\begin{array}{lllll}\text { berkurang } & R p & 200 \quad \text { triliun. }\end{array}$ http://industri.kontan.co.id/news/hippindo-hingga-akhir-tahun-penjualan-ritelterancam-berkurang-rp-200-triliun

Legowo, A. C., \& Noer, B. A. (2017). Pengembangan Model Penerimaan Social Media Marketing Di Kalangan Mahasiswa. Al Ulum Jurnal Sains Dan Teknologi, 3(1), $1-8$.

Limilia, P., \& Pratamawaty, B. B. (2020). Google Trends and Information Seeking Trend of COVID-19 in Indonesia. Jurnal ASPIKOM, 5(2), 188. https://doi.org/10.24329/aspikom.v5i2.741

Mazaheri, E., Richard, M., \& Laroche, M. (2012). The role of emotions in online consumer behavior: A comparison of search, experience, and credence services. Journal of Services Marketing, 26(7), 535-550. https://doi.org/10.1108/08876041211266503

Miles, M. B., \& Huberman, A. M. (1984). Qualitative Data Analysis: A Sourcebook of New Methods. Sage Publications, Newbury Park.

Nunez-Zabaleta, A. (2019). Social Media for Business Purposes: Objectives Pursued and Satisfaction in the Results. International Journal of E-Business Research, 15(3), 35-50. https://doi.org/10.4018/IJEBR.2019070103

Olanrewaju, A.-S. T., Hossain, M. A., Whiteside, N., \& Mercieca, P. (2020). Social media and entrepreneurship research: A literature review. International Journal of Information Management, 50, 90-110. https://doi.org/10.1016/j.ijinfomgt.2019.05.011

Paxel. (2021, January 7). Paxel Buy \& Send Insights: UKM Prefer to Sell in Social Media. https://paxel.co/en/news-and-promos/detail/2020-05-05/paxel-buy-andsend-insights-ukm-lebih-suka-berjualan-di-media-sosial

Rahbi, A. L., \& Abdullah, H. S. (2017). Factors influencing social media adoption in small and medium enterprises (SMEs) [PhD Thesis]. Brunel University London.

Riyanto, A. D. (2020). Hootsuite (We are Social): Indonesian Digital Report 2020 Andi Dwi Riyanto, Dosen, Praktisi, Konsultan, Pembicara: E-bisnis/Digital 
Marketing/Promotion/Internet marketing, SEO, Technopreneur, Fasilitator Google Gapura Digital yogyakarta. https://andi.link/hootsuite-we-are-socialindonesian-digital-report-2020/

Simangunsong, E., \& Handoko, R. (2020). The Role of Social Media in Indonesia for Business Transformation Strategy. INTERNATIONAL RESEARCH JOURNAL OF BUSINESS STUDIES, 13(1), 99-112.

Statista. (2020, July 24). Internet users in the world 2020. Statista. https://www.statista.com/statistics/617136/digital-population-worldwide/

Stemler, S. (2001). An overview of content analysis. Practical Assessment, Research \& Evaluation, 7(17), 137-146.

Tjepkema, L. (2019, January 3). Top 5 Social Media Predictions for 2019 [Top 5 Social Media Predictions for 2019]. Emarsys. https://emarsys.com/learn/blog/top-5social-media-predictions-2019/

Yin, R. K. (2013). Case Study Research: Design and Methods. Sage publications. 